\title{
'n Bybelstudieboek vir vroue oor heelwording
}

\begin{abstract}
Book Title:
Eva het haar toonnaels rooi geverf
\end{abstract}

Book Cover:

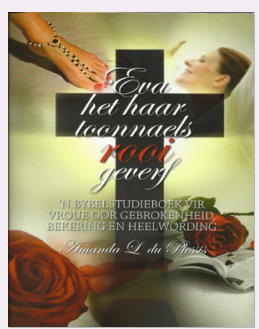

Author:

Amanda du Plessis

ISSN:

978-0-86955-214-8

Publisher:

Potchefstroom Theological

Publications, 2013, R120.00*

*Book price at time of review

Review Title:

'n Bybelstudieboek vir vroue oor heelwording

Reviewer:

Madelein Fourie ${ }^{1}$

\section{Affiliation:}

${ }^{1}$ Faculty of Theology,

North-West University,

Potchefstroom Campus,

South Africa

Email:

madeleinfourie@telkomsa.

net

Postal Address:

PO Box 1723, Kroonstad

9500, South Africa

How to cite this book review:

Fourie, M., 2014, "n

Bybelstudieboek vir vroue

oor heelwording', In die

Skriflig 48(1), Art. \#1804,

1 page. http://dx.doi.

org/10.4102/ids.v48i1.1804

Read online:

口ition Scan this $Q R$

code with you

smart phone or

mobile device

to read online.
Eva het haar toonnaels rooi geverf is 'n Bybelstudiegids wat oor die potensiaal beskik om op só 'n wyse met vroue te spreek dat 'n veranderde lewenswyse tot eer van God en 'n verdiepte persoonlike verhouding met ons Hemelse Vader vir haarself en haar eggenoot die uitkoms is.

Hierdie publikasie is 'n eerste poging uit die pen van Amanda du Plessis. Die hartseer van vroue, die geloofsuitdagings en die gebrokenheid waarmee vroue gekonfronteer word, lê die skrywer na aan die hart. Du Plessis beywer haar vir die heelwording, genesing en bemagtiging van vroue. Sy is ' $n$ pastorale berader van beroep en is nóu by die terapeutiese helingsprosesse van seerkryvroue betrokke.

Die titel van die boek verwoord iets van 'n opgewonde nuuskierigheid met'n onmiddellike reaksie: Waarom het Eva dan haar toonnaels rooi geverf? Die antwoord verras. Alhoewel skoonheid 'n wesenlike deel van elke vrou is, is die waarde van vroue nie slegs ingebed in voorkoms en dit wat sy bereik het nie. Sy is júís waardevol omdat sy in 'n lewende verhouding met God leef!

Die inhoud van die boek pas soos boublokke op mekaar en die onderste blok, die fondasie, is gesetel en geanker in 'n verhouding met God. Eva is deurentyd aan die woord met 'n eie narratief waardeur sy 'n insiggewende perspektief op haar belewenisse bied.

Uit hierdie kosbare lesse van Eva kan die hedendaagse vrou meer oor haar verhouding met God, 'n verhouding met haarself en ook haar verhouding met haar eggenoot leer. Hierdie drie lewenslesse word onderskeidelik in drie afdelings toegelig en bied die geleentheid vir geestelike groei.

In die eerste lewensles leer die vrou wat dit behels om in 'n verbondsverhouding, 'n persoonlike verhouding met God, te staan. Verskillende geestelike dissiplines en opregte kommunikasie met God geld, waaronder gebed en hoe om God se stem te hoor. Die tweede lewensles wil die vrou se eiewaarde in God herstel as die kroon van sy skepping. Eva se identiteit in die Here het aanvanklik vanweë die sonde verlore gegaan. Dit is egter wonderlik dat haar gebrokenheid deur die genade van God herstel kon word. Vandag is God se onbeskryflike genade steeds tot die beskikking van elke vrou - om die skeefgetrekte eie-prentjies te genees en tot 'n goddelike beskouingsbesef te verhef.

Die derde en laaste les bied 'n veranderde blik op die huwelik. Die verbondsaspek van die huwelik word onderstreep. Aan die hand van goue rë̈ls vir die huwelik is dit moontlik om jou eie huwelik te evalueer en te vind dat eenwording werklik tot heelwording lei. Die riglyne, besprekingsgedagtes en gebed wat deur die skrywer gebied word, dra by tot die aktiewe deelname van die leser. Die leser word die geleentheid gebied om individueel of in groepsverband verder te besin ten einde verstandskennis in hartskennis te transformeer.

Hierdie publikasie is mooi geskryf. Dit resoneer met die skoonheid van die vrou en spreek tot die siel. Begrippe soos verbond, geestelike dissiplines, genade, vergifnis en versoening is soms moeilik verteerbaar. Dit word egter op ' $n$ treffende en verstaanbare wyse deur die skrywer toegelig.

Ten slotte word hierdie boek vir elke vrou aanbeveel. Elke vrou wat ten diepste dors en verlang na 'n opregte verhouding met God, wat moontlik sukkel met gevoelens van negatiewe selfwaarde of vasgevang is in ' $n$ huweliksverhouding wat nie wil vlot nie, sal hierdie Bybelstudiegids met groot vrug kan gebruik. Dit is 'n insiggewende, praktiese en waardevolle boek vir Bybelstudiegroepe of vir die individuele leser. Dit beloof veranderde denke en hartsbegeertes, heelwording en 'n verdiepte persoonlike verhouding en lewenswyse voor God.

Copyright: (C) 2014. The Authors. Licensee: AOSIS OpenJournals. This work is licensed under the Creative Commons Attribution License. 